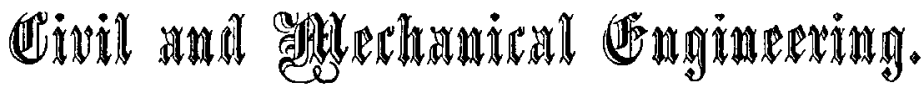

\section{PENNSYLVANIA RAILROAD GRAIN DEPOT, WEST PHILADELPHIA،}

BY Jos. M. WIr.son, C. E. P. A., Engineer Construction Department P. R. R.

Thrs building is located on the east side of 30th Street, just north of Market. It is intended as a depot for receiving grain directly from cars and delivering expeditiously into wagons by which it can be transported to the warehouses of the owners. It is 555 feet in length, 125 feet in width and 36 feet from ground line to eaves, being divided into two stories by a floor 19 feet above the ground linc. The roof is a single span having a one-quarter pitch, and built of wrought iron, upon the simple triangular truss system, with timber principal rafters. It is covered with slate and has, at frequent intervals, sky-lights of hammered glass. The balance of the building is constructed entirely of timber, the sides being sheeted and slated. The total content, comprised within the outside walls and from ground line to slope of roof, is $3,607,500$ cubic feet. The cars enter the second story by six tracks running its entire length. Between the tracks the platforms are 4 feet above the rail. Underneath, from the platforms down to eight feet above the lower floor or ground line, the whole of the space is put into bins. From the cars the grain is shoveled directly into upper openings in the bins, which are 11 feet apart on either side of each track. There is a sliding valve in each bin, at the bottom, by which the grain can be passed directly into wagons underneath by its own gravity, the sides of the bins being sloped at such an angle as will insure its delivery. The total number of bins in the building is 600 , and the average capacity of each 500 bushels, giving a total capacity of 300,000 bushels. By a system of duplicate numbers on the upper and lower openings of bins, the grain of different shippers can be kept separate and distinct, and is transferred from car to wagon without confusion. Wagons enter the ground floor by 50 passage ways running in the direction of the width of the building and separated by trestles eleven feet apart, which support the upper floor. These passage ways are directly under the lower openings of the bins, and are closed by doors at each end. On the platforms between the tracks on second floor, flour in barrels may be un.

VOL. LIX.-ThIRD SERIES. -No. 1. -J INUARY, 1870. 
loaded, and at the east end of the building, on the outside, a block and tackle is arranged for each platform to facilitate lowering the flour to a wharf beneath.

The ground upon which the building is ereeted being artificially made, upon a bed of river mud of considerable depth, it was decided to use piles in the foundations. Excavation to the depth of six inches above ordinary high water was commenced in November, 1868. Upon this bottom, which was just above the level to which water came through the ground from the river, the pile drivers were placed. The first pile was driven November 30th; and the driving was continued at the following rates: December, 316 ; January, 655; February, 544; March; 428; April, 1079; May, 1184 ; June, 1352. Making a total of 5,558, of which 5,175 were under the main building and 383 under the retaining walls of ap. proaches. There were three pile drivers. Two were worked by engines stationed on the land and one by an engine on a scow on the river. Of the land engines, sometimes both were working and a part of the time only one. The river engine worked only occasionally, being used principally to hoist timber from the river. The supply of timber for piles was quite limited during the winter and gave out entirely in March, so that the driving had to stop until the spring freshets brought down a new lot. The piles along the cast or river front were driven to an average depth of 33 feet below ordinary high water before reaching hard bottom. At 150 feet from the east end the average depth was 35 feet; at 300 feet, 34 feet; at 400 feet, 32 feet; at 450 feet, 24 feet; at 500 feet, 14 feet; at 520 feet, 6 feet; and from here to the west end of the building it increased to 19 feet. The piles were of straight growth Hemlock not less than ten inches diameter at the head, which was hooped with a wrought iron band. Under the outside walls they were driven in three rows, and under the interior or cross walls in two rows, being placed $2 \frac{1}{2}$ feet between centres across the rows, and three feet between centres lengthwise of the rows. After they were driven the earth was excavated around them to a debt of $2 \frac{1}{2}$ feet below ordinary high water, and they were sawed off at that elevation. A cap of flattened Hemlock logs, 9 inches thick and average 15 inches in width on face, was laid upon each row and pinued to the piles by locust pins. Upon this a second course of similar logs, not less than six inches in thickness, was placed crosswise and fastened, thus forming a floor upon which the masonry was built. The plat- 
forms of the cross walls were securely tied together by logs of the upper course at intervals of about every 15 feet. The masonry was commenced in March and followed up the pile driving closely: The outside walls are 4 feet thick at bottom, and are carried up to $10 \frac{1}{2}$ feet above ordinary high water, diminishing by steps to $2 \frac{1}{2}$ feet thickness at top. The cross walls are 3 feet thick at bottom, and are carried up to $12 \frac{1}{2}$ feet above ordinary high water, diminish. ing to 2 feet thickness at top. The whole of the foundations between the masonry was filled up with earth to one foot below top of cross walls, and on a level with 30 th Street.

The tracks running on to second floor cross 30th Street by a wrought iron elliptical braced arch bridge of 64 feet 1 inch span and 11 feet $11 \frac{3}{4}$ inches rise at the crown. Although not strictly novel in its design, yet it is believed to be the first of its kind put up in this country. It is hinged both at orown and springing, thus reducing the calculations to a certainty not possessed by the ordinary form of arch, and annulling the straining effects due to change of temperature or yielding of piers. The plans and specifications for both bridge and building were furnished complete by the Construction Department of the Pennsylvania Railroad, and the work executed under its superintendence, although the most of it was done by contract.

\section{PERFORMANCES OF ENGINEŚ.}

BY W. H. G. West, Enaineer, U. S. N.

THE following is a statement of the performances of a number of engines, collected from different quarters, by engineers of un. doubted knowledge and integrity.

Condensing cotton mill ergine at Chester, $\mathrm{Pa}$. Diameter of cylinder $20^{\prime \prime}$. Stroke 4 feet. Steam cut off about one foot from com. mencement of stroke. Steam pressure 61 pounds above atmospheric. Boiler, tubular: locomotive pattern. Coal consumed per horse-power per hour, 2.35 pounds. Duration of trial 60 hours. For one day of the trial the consumption was only 2.057 pounds per hour, for each horse-power. Chestnut coal gave the best result; and if used during the whole trial, would probably have brought the consumption below 2 pounds.

Non-condensing cotton mill engine. Diameter of cylinder $14^{\prime \prime}$. Stroke 3 feet. Cut off at about $\frac{1}{5}$ of stroke from commencement. 
Cylinder boilers. Steam 80 pounds above atmospheric. Consump. tion of coal 3 pounds per horse-power per hour.

Condensing cotton mill engine. Diameter of cylinder $28^{\prime \prime}$. Stroke 5 feet. Steam pressure 110 pounds above atmospheric. Cut off varied by regulator. Jacketed cylinder. Tubular boilers. Consumption of coal per horse-power per hour, 1.9 pounds.

Brooklyn Water Works Engine.-Diameter of cylinder, 90" Stroke 10 feet. Flue boilers. Consumption of coal per horsepower per hour 3 pounds.

Average performance of a number of stationary engines of and about $20^{\prime \prime}$ diameter of cylinder, $4 \frac{1}{2}$ pounds of coal per horse-power per hour.

Babcock and Wilcox engine, Jacketed, $3 \frac{1}{2}$ pounds.

Greene's engine, $3 \frac{3}{4}$ pounds.

Corliss engine, non-condensing, $3 \frac{1}{2}$ pounds.

Average performance of a number of Cornish engines. Diame. ter of cylinders $50^{\prime \prime}$ and upwards; about $3 \frac{3}{4}$ pounds per horsepower per hour.

U.S. S. "Wampanoag," running 18 to $20 \frac{1}{2}$ statue miles per hour, after making all allowances for friction of load, etc., and so bring. ing it to the same condition, in regard to duty, as the Cornish engine, 3.129 pounds per horse-power per hour.

U.S. S. "Ammonoosuc," running 18 to 20 statue miles per hour, 2.65 pounds per horse-power per hour.

H. B. M. ship "Constance," Woolfe engines, with jacketed cylinders. Steam expanded from 8 to 10 times. Surface condenser. Consumption of coal per horse-power per hour, 2 pounds.

In presenting these proofs of the correctness of a former assertion that many American, and other rotative engines, will compare favorably with the majority of Cornish engines, I do not wish to imply that the above performances are the best obtained from the engines named, but that they are sufficient to prove more than equality. In collecting them, I have been forced to the conclusion, that either the construction of the Cornish engine is not particularly well understood, by the present manufacturers of that inter. esting machine, or that the old plan of guessing at coal, by the barrow load, led the experimenters, of that time, astray.

More than twenty years ago the duty was said to have come up to $130,000,000$ pounds, lifted one foot high, by the consumption of 112 pounds of Coal; but for May, of this year, the average for 
eighteen of them was only $50,100,000$, and it will be found that this is the general average.

Several writers have distinctly stated, in the Journal, that the weight of the moving parts is the principal cause of the superiority of this engine, and much importance is attached to the fact of its having a beam, but we know very well that the weights are nearly the same as in old times, and that the weight of the engine beam is exceedingly small, when compared with the weights of rods balance-beams, etc., which belong to the pumping apparatus, and which must be used with any kind of engine that may be cmployed. Can prejudice possibly be so strong as to compel any one, even to insinuate, that a slight variation, in the strength of parts, will make a difference of $80,000,000$ pounds in the duty.

In accepting, as sound, the arguments of the gentlemen who have recently written so warmly and forcibly in favor of these engines; there is nothing left but to believe that those built in late years are very badly designed. Mr. William West, the designer of the $80^{\prime \prime}$ at Fowey Consols, would not feel complimented, were he to hear that the success which he sought to achieve by improve. ment in every detail, was due to clumsy bulkiness.

It is stated in a paper upon steam jacketing that, practically, the expansion of metal is nothing, in the cornish engine cylinder. This is repeating the old story, that theory does not agree with practice, and is an expressed doubt of the ability of such men as Joule, Faraday, 'Iyndall, Regnault, and others of cqually high reputation, to make practical experiments. A beautiful set of experiments is recorded in the November number for 1869 , showing the number of vibrations of piano strings in making the different notes; but practically, we have every reason to doubt the truth of the statement, because we do not see the strings flap about, like the sails of a ship, tacking in a gale of wind.

At one end of the Cornish cylinder we have a high pressure, say 60 pounds, the temperature of which is $292 \cdot 6$ degrees, Fabr. and at the other end $90^{\circ}$-condenser temperature. Cast iron expands lineally .00000618 per unit, for each degree of heat added about these temperatures. An $80^{\prime \prime}$ cylinder will therefore increase its diameter full 0.1 inch. The temperature of the piston will be a mean between the other two, and the thickness of the piston being about ten times greater than that of the cylinder, its temperature will not change as rapidly: indeed its diameter will be nearly con- 
stant. If it fits well at one end, it must therefore jam, or leak steam at the other. Practically, my attention was first drawn to it by one who had observed it in the Fowey Consols $80^{\prime \prime}$ when an attempt was made to move her, before the stcam, passing from the boiler to the jacket, had heated the cylinder all through. After steam had been admitted to the lower end, the engine worked as usual. The difference of temperatures, in that case, was probably $250^{\circ}$; and the difference of diameters almost exactly $\frac{1}{8}$ inch. In the same circumstances, the 110 inch cylinder, now being made for the Bethlehem Zinc Mine, Pa., would have a difference of diameter of over ${ }_{6}^{\prime}$ inch; and the 144 inch built by Harvey and West, of Hayle Foundry, Cornwall, England, for Holland, would have a difference of diameters of 0.22 inch (nearly $\mu_{4}^{\prime \prime}$.) Would that be a practical leak? The very high steam that some people say is used in Cornish engines, would make the leak greater.

Rankine, in his "Prime Movers," page 568, compares the effects produced with, and without, the steam jacket. The ratio of whole gross work of steam to gross work during admission, will show which does the most work during expansion and will be mean pres. $X$ ratio of expansion initial pressure $=3.55$, for the unjacketed cylinder, and 3.73 for the jacketed oylindor; showing decidedly in favor of the jacket. Condensation in the cylinder, is shown by the ratio $\frac{\text { initial pressure }}{\text { mean pressure }}=5.64$ for unjacketed cylinder, and $5 \cdot 36$ for jack. eted cylinder; giving a much greater condensation, in the unjacketed cylinder.

The same writer, for the Journal, says, that "there is no doubt that a higher degree of expansion is possible with a steam.jacketed cylinder." There lies economy.

I cannot sec how admitting more steam, alrcady on the point of condensation, can prevent other steam, with which it is brought into contact, from condensing, as all must expand together.

Steam, in the steam jacket, superheats the expanding steam in the cylinder, by the loss of its own heat, and thereby prevents con. densation in the cylinder, to a great extent. It is not supposed to vaporize any that may lie upon the piston, except through the superheated steam in the cylinder.

Two questions arise in regard to steam jacketing. 1st.-Whether it is better to condense steam in the cylinder, thus assisting the 
condensation by expansion, and to expand the remaining low steam, or to condense steam in the jacket, and get the benefit arising from the use of high steam, together with the increased economy of a high grade of expansion. 2nd.-Whether the heat remaining in the water, into which the steam is converted, should go to the con. denser to destroy the vacuum, and the water itself to load the pumps or go back to the boiler, for further use. I should say the latter, in each case. Although it is very right, and proper, for each one to judge for himself, some little weight should be given to the experience of Watt and other prominent men who have pronounced in favor of the steam jacket.

In the August number of 1869 , page 11, we find the following. "A Cornish engine is now running which produces a lower duty than a double acting high pressure fly-wheel engine, used in tho same works illustrating defects in construction." This assertion is, without doubt, true, and the writer probably refers to the wonderful thing recently built for Spring Garden or some other Philadelphia Water Works, but which is really not a Cornish engine; or to that singular pair of twins in the Wcst Philadelphia Water Works, that were designed to be Cornish engines, but are not, and which obstinately persisted, for a long time, in pumping water during the latter part of the stroke, only. I am glad to see that some one has the courage to compare them (unfavorably too) with the least economical type of rotative engine.

In the editorial note, September number, 1869 , page 159 , we find it stated that eighteen Cornish engines averaged a duty of only $50,100,000$ pounds, lifted one foot high, by a consumption of 112 pounds of coal, or 447,321 foot pounds for one pound of coal. A horse-power means 33,000 pounds lifted one foot high, in a minute, or $1,980,000$ pounds, lifted one foot high, in an hour. Dividing this by the number of pounds of coal consumed per horse-power per hour, we have the number of pounds, lifted one foot high, by the consumption of 1 pound of coal, and proceeding thus with the statistics already given, we have the following results, showing the comparative economy of the different engines.

\begin{tabular}{|c|c|c|c|c|c|c|c|c|}
\hline \multicolumn{9}{|c|}{ At $1-9$ pounds per horse power........... 1,042,105 ft. $1 \mathrm{bs}$. for 1 pound of coal. } \\
\hline “2. & “ & “ & “ & n........... & 990,000 & a & 16 & 6 \\
\hline “ $2 \cdot 65$ & " & is & “ & ........... & 747,169 & " & " & ، \\
\hline " 3 & " & ↔ & a & & 660,000 & ، & $6 t$ & .6 \\
\hline “ 3.125 & $" 1$ & 16 & 66 & .. & 632,790 & "6 & "6 & " \\
\hline " 4.5 & " & 16 & “ & $\ldots \ldots$ & 440,000 & “6 & “ & ، \\
\hline 163.75 & 16 & " & "6 & ....... & 528,000 & 16 & If & 66 \\
\hline$\therefore 4.42$ & " & " & 4 & ,............. & 447,321 & "6 & " & 16 \\
\hline
\end{tabular}


The next to the last is the average of a number of Cornisin engines, collected for this paper.

The last is the average of eighteen, given by the editor.

Fowey Consols $80^{\prime \prime}$-exceptional- $1 \cdot 7$ pounds per horse-power per hour, gives $1,160,714$, for consurnption of 1 pound of coal, or $130,000,000$ for 112 pounds.

Rowans engine-exceptional--1.12 pounds per horse-power per hour, gives $1,767,857$ for one pound of coal, or nearly $198,000,000$ for 112 pounds.

After all that has been written about duty, in the January and August numbers of the Journal, for 1869, engineers, and other scientific men, will be as much astonished as $I$ am, to find that most Cornish engines, of the present day, are very poor machines, and that several other classes of engines are superior; amongst them the much abused marine engine, which does the same amount of work with about one-half the coal consumed by the Cornish engine.

There is every reason to believe that if all attending circumstances were noted, and given due consideration, neither Rowan's enginc, nor the Cornish engine, would have shown anything like tho duty accredited to tbem. It is impossible to accept the belief that engineers of our day, in spite of their advances in scientific knowledgc, are incapable of building a good pumping engine, and it is far more probable that these high duties are the results of very short, and imperfectly constructed, experiments. It must be remembered that there is a limit to the ability of stenm to do work, even allowing it all that is claimed by Marriotte.

\section{THE MOUNT WASHINGTON RAILWAY.}

ABout a dozen years ago, Mr. Sylvester Marsh, then of Chicago, conceived the idea of constructing a railway up the rugged slopes of the White Mountains of New Hampshire, with a novel outfit of rolling stock, capable, as he believed, of transporting the throng of summer visitors to the summit of Mount Washington, 6000 feet above the sea level, on grades of 1 in 3 . The boldness of the plan, emanating from a man who laid no claim to professional knowledge, caused it to be looked upon as visionary and impractible. For a long time Mr. Marsh vainly importuned engincers and capitalists to endorse his scheme. A small model of his track and machinery was on exhibition for years in the Merchants' Exchange of Boston 
without attracting any effective attention, and his application to the Legislature of New Hampshire for a charter was granted almost by default, nobody believing that it would ever be heard of again. But the projetor was persevering, and at length succeeded in enlisting the attention of parties interested in the various lines of railway over which the summer travel passed to and from the mountains. By their aid, in 1866, a short piece of experimental track was laid up the lower slope of the mountain, and an engine built to attempt the ascent. The experiment was successful. Capital was obtained to push it further, and in August, 1868, the line was opened for travel to a point within three-fourths of a mile of the summit, and at the commencement of the season of 1869 it was completed and put in use to the tip-top house, on the crown of the mountain.

At first the nervous travellers avoided the very airy looking conveyance, and only the bolder half tricd the new and easy mode of ascent. A still smaller proportion attempted the descent, which was the most fearful looking of the two. But as no accident occurred-and it was demonstrated that ample provision had been made for the ordinary breakages and derangement of machinery or tracks-confidence was established, and the road obtained all the patronage that its equipment could accommodate. In illustration of its apparent safety, it may be stated that more than nine thousand tons of construction material have been transported over it, and great numbers of passengers, without accident or injury to property or person, the only individual ever injured being one of the workmen, who, having a careless habit of taking an easy way of getting down one of the steep inclines by placing a board on the centre track and sliding upon it, came to grief and a broken leg one day for want of a suitable brake on his machine.

The road bed of this extraordinary structure is mainly a timber trestle work, cut from the forest of spruce that covers the lower slopes of the mountain. The rails are of the ordinary strap pattern on longitudinal timbers, with a gauge of about $4 \mathrm{ft}$. In the middle of this track a third longitudinal timber is securely fastened, and surmounted with a heavy rack or ladder of wrought iron, into which steel pinions work from the engine and car, the motive power being a locomotive engine working through counter-shafts and pinions into this fixed rack. Iron pendants from the engine and car with flanges turning under the longitudinal timbers prevent the Vol. LIX.-Third SEries.--No. 1.-January, 1870. 
possibility of the train being lifted from the track by wind or other force, and by a combination of atmospheric brakes and brake straps on the pinion shafts the train can be stopped under all emergencies.

The engine is placed below the car, and retains its position both in the ascent and descent. It has an upright boiler and horizontal cylinder, with crank rod continuation of the piston, like an ordi. nary locomotive. The weight is about 7 tous.

The car body is of the ordinary American pattern, but about half the common size and capacity, mounted on four wheels only. The weight is about 4 tons, and the seats are placed as in a common American car, and so hung on stirrups as to retain their horizontal position under all circumstances, an advantage which is quite manifest when the incline brings one end of the oar 30 feet higher than the other.

The time occupied in the ascent or descent of the three miles of railway is about one hour. The maximum grade is 1700 feet to the mile, and the average grade, from the elevated platform, where the road now starts at the foot of the mountain, is 1300 feet per mile.-Engineering.

\section{BELTING FACTS AND FIGURES.}

By J. H. COOPER.

(Continued from page 385 .)

WE take the following series of interesting facts from "Practical Treatise on Mill Gearing." By Thomas Box, London: E. and F. N. Spon, 1869.

Driving Power of Belts.-Let A, in Fig. 1, be a pulley fixed

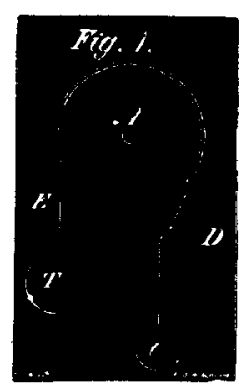
so as to be incapable of turning, and $\mathrm{T} t$ weights suspended by a belt $\mathrm{E}$, which passes round the pulley, and may be caused to embrace it more or less by a small guide-pulley D. Let now the weight $\mathrm{T}$ be increased until the friction of the belt is overcome, and it slips on the pulley, the weight $\mathrm{T}$ descending.

The ratio between $\mathrm{T}$ and $t$ varies-

1st. With the coefficient of friction of the ma. terial of the belt $\mathrm{E}$, sliding on the material of the pulley A. 2d. With the proportion which the arc of the pulley embraced, bears to the whole circumference of the pulley. 